\title{
Kajian Pola Ornamen (Ragam Hias) Bernuansa Melayu untuk Fasade Bangunan Publik di Kota Pontianak
}

\author{
Wahyudin Ciptadi, Erwin Rizal Hamzah, \& Dewi Ria Indriana
}

\author{
Jurusan Teknik Arsitektur Politeknik Negeri Pontianak \\ Jalan Ahmad Yani, Pontianak Tenggara, Pontianak 78124 \\ Email :wahyudinciptadi07@gmail.com
}

\begin{abstract}
There is a phenomenon in the Regional Government of Pontianak City in realizing a public building facade, especially office functions that have a local identity value, which are required to apply the use of distinctive local ornaments (ornaments). One of the local ornaments (decorations) that will be used in public buildings in Pontianak is the Pontianak Malay nuances. The use of local ornaments (ornaments) that are applied in public buildings in the city of Pontianak is heavily influenced by elements found in traditional Pontianak Malay houses and from the Pontianak Kadriah Palace.The determine benchmarks aspects in discussing the study of ornamental patterns in a building, namely by using a model system (stylistic system) from the theory of N.J. Habraken (1978). System model (stylistic system) is a method used to determine benchmarks related to style or style including facades, door and window shapes and ornamental elements (decoration) both in the upper (head), middle (body) elements. ), and elements of the bottom (foot) of the building. In this applied research, the object of his research is the pattern of ornaments (decorative styles) with Pontianak Malay nuances used in traditional Pontianak Malay houses and the Pontianak Kadriah Palace. This applied research aims to compile and study a database of Pontianak Malay nuances of ornamental patterns so that they can be used for the design of public buildings in Pontianak, especially office functions. This applied research uses a rationalistic-qualitative approach by taking several research samples from the Pontianak Kadriah Palace and the population of traditional Pontianak Malay houses that are in 3 (three) communality zones. This study uses several stages of the implementation process, namely: the data collection stage (initial observation, follow-up observation, and interviews) and the data analysis stage and discussion of the research results. The expected result of this applied research is the compilation and documentation of a database of ornamental patterns with Pontianak Malay nuances that can be used for the design of public building facades in Pontianak, West Kalimantan.
\end{abstract}

Keywords: patterns, ornaments (decoration), Malay nuances, facades, public buildings

Abstraks: Terdapat fenomena di Pemerintah Daerah Kota Pontianak dalam mewujudkan sebuah fasade bangunan publik khususnya fungsi perkantoran memiliki nilai identitas daerah setempat diharuskan menerapkan penggunaan ragam hias (ornamen) lokal yang khas. Ornamen (ragam hias) lokal yang akan digunakan pada bangunan publik di kota Pontianak yaitu salah satunya ornamen (ragam hias) bernuansa Melayu Pontianak. Penggunaan ragam hias (ornamen) lokal yang diterapkan di bangunan publik kota Pontianak banyak dipengaruhi oleh unsur-unsur yang terdapat pada rumah tradisional Melayu Pontianak dan dari Istana Kadriah Pontianak. Untuk menentukan aspek-aspek tolok ukur dalam membahas kajian pola ornamen (ragam hias) di sebuah bangunan yaitu dengan menggunakan sistem model (stylistic system) dari teori N.J.Habraken (1978). System model (stylistic system) adalah cara yang digunakan untuk menentukan tolok ukur yang berkaitan dengan style atau langgam meliputi fasade, bentuk pintu dan jendela serta unsur-unsur ornamen (ragam hias) baik di elemen bagian atas (kepala), elemen bagian tengah (badan), dan elemen bagian bawah (kaki) bangunan. Dalam penelitian terapan ini yang menjadi obyek penelitiannya adalah pola ornamen (ragam hias) bernuansa Melayu 
Pontianak yang digunakan di rumah tinggal tradisional Melayu Pontianak dan Istana Kadriah Pontianak. Dalam penelitian terapan ini bertujuan menyusun dan mengkaji database pola ornamen (ragam hias) bernuansa Melayu Pontianak agar bisa digunakan untuk desain fasade bangunan publik kota Pontianak khususnya fungsi perkantoran. Penelitian terapan ini menggunakan pendekatan metode rasionalistik-kualitatif dengan mengambil beberapa sampel penelitian dari Istana Kadriah Pontianak dan populasi rumah tinggal tradisional Melayu Pontianak yang berada dalam 3 (tiga) zona komunalitas. Dalam penelitian ini menggunakan beberapa tahapan proses pelaksanaan yaitu : tahap pengumpulan data (observasi awal, observasi lanjutan, dan wawancara) dan tahap analisis data serta pembahasan hasil penelitian. Hasil yang diharapkan dari penelitian terapan ini adalah tersusunnya dan terdokummentasinya database pola ornamen (ragam hias) bernuansa Melayu Pontianak yang bisa digunakan untuk desain fasade bangunan publik kota Pontianak, Kalimantan Barat.

Kata Kunci : pola, ornamen (ragam hias), nuansa Melayu, fasade, bangunan public

Kota Pontianak merupakan ibukota Provinsi Kalimantan Barat yang melayani hampir seluruh aktivitas administrasi pelayanan publik setingkat provinsi dan kotamadya, dengan fasilitas bangunan publiknya. Penerapan ornamen (ragam hias) pada fasade bangunan publik di kota Pontianak sudah mulai hilang seiring perkembangan zaman padahal hal ini sangat penting untuk menjaga nilai budaya. Perlu diketahui, ornamen (ragam hias) menjadi suatu ciri khas tersendiri suatu daerah agar mudah dikenali atau diidentifikasi oleh khalayak ramai sebagai suatu ciri khas kota Pontianak.

Bentuk dan fasade dari bangunan publik dipengaruhi oleh faktor lingkungan dan perkembangan budaya. Untuk itu Pemerintah Daerah Kota Pontianak dalam mewujudkan sebuah fasade bangunan publik yang memiliki nilai identitas daerah setempat diharuskan menerapkan penggunaan ornamen (ragam hias) lokal misalnya ornamen (ragam hias) yang bernuansa melayu Pontianak.

Pada bangunan publik di kota Pontianak dalam penerapan ornamen (ragam hias) pada bangunan dijadikan sebagai aksen dan wujud berupa pola-pola ornamen yang khas,. Bahkan beberapa bangunan publik dapat tampil detil namun tetap dapat memunculkan keindahan. Bangunan seperti itu keindahannya dapat dimunculkan dari bentuk dan motif ornamen serta karakter bahan yang digunakan. Penggunaan ragam hias (ornamen) lokal yang diterapkan di bangunan publik kota Pontianak banyak dipengaruhi oleh unsur-unsur yang terdapat pada rumah tradisional Melayu Pontianak dan dari Istana Kadriah Pontianak.

Rumah tinggal tradisional Melayu Pontianak adalah sebuah rumah tinggal yang memiliki nilai kekhasan ragam hias dan ornamentasi tersendiri dengan daerah lain karena dipengaruhi oleh ajaran Agama Islam, adat istiadat Melayu Pontianak, dan dari Istana Kadriah Pontianak yang masih bertahan sampai saat ini. Untuk pengelompokan tipe (jenis) ornamen (ragam hias) rumah tinggal tradisional Melayu Pontianak berdasarkan tingkatan hirarki tertinggi yaitu terbagi atas tipe Potong Kawat, tipe Potong Godang, dan tipe Potong Limas.

Arsitektur tradisional rumah Melayu Pontianak meliputi bentuk bangunan, struktur bangunan, ragam hias, fungsi dan cara pembuatan bangunan rumah yang diwarisi secara turun temurun dan tidak terlepas dari faktor lingkungan tempatnya terbentuk. Rapoport (1969) menyatakan bahwa rumah tradisional merupakan suatu gejala struktural yang bentuk dan organisasinya sangat dipengaruhi oleh lingkungan budaya yang dimilikinya, serta erat hubungan dengan kehidupan penghuninya. Makna simbolisme dan fungsi ornamen (ragam hias) akan mencerminkan status penghuninya.

N.J.Habraken (1978) juga mempertegas pernyataan ini dengan menyatakan bahwa arsitektur tradisional rumah Melayu Pontianak merupakan suatu kesatuan sistem yang terdiri 
atas Spatial System, Physical System, dan Stylistic System. Stylistic System meliputi aspek tolok ukur yang berkaitan dengan masalah style atau langgam ornamen (ragam hias) yang mewujudkan bentuk. Sistem ini meliputi fasade bangunan, bentuk pintu dan jendela serta unsur-unsur ornamen baik di dalam maupun di luar bangunan dari elemen atas (kepala), elemen tengah (badan), dan elemen bawah (kaki) di rumah tinggal tradisional Melayu Pontianak.

Fasade bangunan merupakan wajah bangunan yang pertama kali dilihat. Salah satu hal yang menarik pada fasade adalah ornamennya. Ornamen merupakan elemen visual yang berfungsi sebagai unsur estetika guna memperindah bangunan serta memiliki fungsi lain tertentu. Pengungkapan karakter suatu bangunan dapat diidentifikasi dari ornamen serta fasadenya. Salah satu hal yang menarik pada fasade suatu bangunan adalah ornamen (ragam hias)nya. Ornamen (ragam hias) merupakan elemen kelengkapan visual yang juga berfungsi sebagai unsur estetika guna memperindah dan menampilkan karakter pada suatu bangunan. Selain itu ornamen (ragam hias) juga memiliki beberapa fungsi seperti fungsi estetis, fungsi simbolis serta fungsi konstruktif. Oleh karena itu ornamen (ragam hias) erat kaitannya dengan karakter suatu bangunan. Pada saat kita membicarakan ornamen (ragam hias), secara tidak langsung kita juga membicarakan tentang suatu karya arsitektur yang bernilai estetis.

Ada fenomena Pemerintah Daerah Kota Pontianak dalam mewujudkan sebuah fasade bangunan publik khususnya fungsi perkantoran memiliki nilai identitas daerah setempat diharuskan menerapkan penggunaan ragam hias (ornamen) lokal yang khas. Ornamen (ragam hias) lokal yang akan digunakan pada bangunan publik di kota Pontianak yaitu salah satunya ornamen (ragam hias) bernuansa Melayu Pontianak.

Dapat diduga ornamen (ragam hias) bernuansa Melayu Pontianak ini banyak dipengaruhi oleh unsur-unsur yang terdapat pada rumah tradisional Melayu Pontianak dan dari Istana Kadriah Pontianak. Dalam penerapannya diberbagai tempat di kota Pontianak banyak sekali ditemukan bangunan publik khususnya fungsi perkantoran yang salah menerapkan atau tidak menggunakan ornamen (ragam hias) lokal (Melayu Pontianak) sama sekali di fasade bangunannya. Ada beberapa faktor yang menyebabkan hal tersebut bisa terjadi, ada kemungkinan belum adanya database berupa dokumen pola ornamen (ragam hias) yang bernuansa Melayu Pontianak untuk diterapkan di fasade bangunan publik.

Dengan melihat fenomena diatas maka peneliti merasa tertarik untuk melakukan penelitian terapan mengenai kajian pola ornamen (ragam hias) bernuasa Melayu Pontianak yang bisa digunakan untuk fasade bangunan publik kota Pontianak khususnya fungsi perkantoran. Dari rumusan masalah di atas maka dalam penulisan penelitian terapan ini dapat disusun menjadi pertanyaan penelitian (research questions) yang harus dijawab dalam penelitian terapan ini, yaitu :

Bagaimana kajian pola ornamen (ragam hias) bernuansa Melayu yang digunakan untuk fasade bangunan publik kota Pontianak, Kalimantan Barat?

Dalam tinjauan pustaka di penelitian terapan ini dipergunakan sebagai dasar pemikiran yang melandasi dan mengarahkan sebuah teori penelitian. Kemudian materi tinjauan teori yang akan digunakan dalam penelitian terapan ini adalah teori-teori yang ada kaitannya dengan : a). kajian pola ornamen (ragam hias) nuansa Melayu Pontianak yang terkait dengan pengertian secara estimologis dan dalam konteks arsitektur; b). definisi fasade bangunan; c). definisi bangunan publik; d). tinjauan sistem model (stylist system) dalam teori N.J. Habraken dan e). rumah tradisional Melayu Pontianak dan Istana Kadriah Pontianak.

Pola atau pattern menurut Poerwadarminta (1976); The Collin's (1986); Oxford and Oxford English (1991); Dagun (1997); dan Sugono dkk (2008) adalah : (1) suatu bentuk struktur dan sistem (cara kerja) yang tetap dan berulang secara teratur; (2) segala sesuatu yang berfungsi sebagai 
pedoman untuk melaksanakan tindakantindakan; (3) susunan bentuk yang tepat; (4) susunan atau konfigurasi; (5) susunan dari bagian-bagian yang membentuk satu kesatuan terpadu; (6) gambar yang dipakai untuk contoh, corak, sistem, bentuk yang tetap, kombinasi sifat kecenderungan yang khas; (7) informasi bentuk pengorganisasian, teknik penyusunan, pedoman, kerangka, cara dan usaha; dan (8) segala sesuatu yang berfungsi sebagai pedoman, susunan dari bagian-bagian yang membentuk suatu kesatuan terpadu dan berkarakter atau gabungan fungsional dari bagian-bagian yang dapat dibedakan.

Dari berbagai pengertian di atas, dapat disimpulkan bahwa pola atau pattern adalah suatu susunan atau konfigurasi yang berfungsi sebagai pedoman (yang dapat menggambarkan suatu kondisi yang dapat berupa bentuk, kombinasi sifat yang khas, susunan atau pengorganisasian, sistem, corak, kerangka, dan cara maupun usaha yang ada) yang membentuk satu kesatuan terpadu yang tetap dan berulang secara teratur.Kemudian untuk pengertian ornamen berasal dari kata ornare (bahasa Latin) yang berarti menghias. Ornamen memiliki definisi hiasan yang terdapat pada elemen bangunan baik yang dilekatkan maupun yang menyatu dengan elemen bangunan tersebut. Setiap hiasan bergaya geometri atau bergaya lain, ornamen dibuat pada suatu bentuk dasar dari suatu hasil kerajinan tangan (perabotan, pakaian dan sebagainya) termasuk arsitektur.

Menurut Danna Marjono (1979) pada hakekatnya ornamen merupakan hiasan-hiasan yang terdapat pada suatu tempat yang disesuaikan dengan keserasian situasi dan kondisi. Ornamen artinya hiasan yang diatur dengan baik dalam bidang maupun di luar bidang tertentu guna mencapai suatu tujuan keindahan. "Ornament is every detail of shape, texture and colour that is deliberately exploited or added to attract an observer" (setiap detail pada bentuk, tekstur dan warna yang sengaja dimanfaatkan atau ditambahkan agar menarik bagi yang melihatnya).

Pada setiap penampilan ornamen dari suatu karya arsitektur dapat dikenal unsur yang tidak dapat dipisahkan dari rasa keindahan manusia. Pemakaian ornamen biasanya terselip suatu pesan tersendiri dan atau merupakan latar belakang budaya yang ada pada saat itu. Ornamen (ragam hias) juga merupakan salah satu unsur yang bisa menunjukkan simbol budaya masyarakatnya sendiri (ciri khas budaya masyarakat).

Sebagai ragam hias simbolis dibuat selain mempunyai fungsi sebagai penghias suatu bangunan juga memiliki nilai simbolis tertentu didalam norma-norma tertentu (adat, agama, sistem sosial lainnya). Bentuk, motif dan penempatannya sangat ditentukan oleh norma-norma adat maupun agama untuk menghindari timbulnya salah pengertian akan makna atau nilai simbolis yang terkandung didalamnya, oleh sebab itu pengerjaan suatu ornamen simbolis hendaknya menepati aturanaturan yang ditentukan. Contoh ornament (ragam hias) ini misalnya motif kaligrafi, motif flora, motif fauna dan motif geometri.

Menurut penelitian yang dilakukan oleh Iswanto, Danoe (2008), beberapa aplikasi ragam hias yang digunakan untuk salah satu upaya melestarikan bangunan tradisional jawa di bangunan era sekarang ini harus memperhatikan posisi dari perletakan ragam hias serta pemahaman makna dari ragam hias tersebut sebelum digunakan. Sedangkan Santosa, Imam (2017) menemukan peran, bentuk, dan fungsi ragam hias yang mempengaruhi atau menggantikannya, serta faktor atau nilai yang melatarbelakanginya. Hasil penelitiannya menunjukkan kandungan gaya ragam hias Islam arabesque bersifat mayoritas dibanding dengan gaya ragam hias lokal. Dengan demikian, peran, bentuk, dan fungsi ragam hias lokal yang selama ini menjadi ciri kebudayaan setempat menjadi minoritas. Temuan lain adalah pada setiap gejala pengadopsian bentuk dan gaya, hampir seluruhnya mengambil cara meniru, menyalin, atau mengimitasi atau copy, karena hanya mengulang-ulang bentuk dan gaya otentik (klasik) demi menjaga keutuhan makna asosiasinya baik secara citra, identitas, maupun makna simboliknya. 
Pemerintah Daerah Kota Pontianak dalam mewujudkan sebuah fasade bangunan publik yang memiliki nilai identitas daerah setempat diharuskan menerapkan penggunaan ornamen (ragam hias) lokal. Ornamen (ragam hias) pada bangunan publik di kota Pontianak dapat diduga banyak dipengaruhi oleh unsurunsur yang terdapat pada rumah tinggal tradisional Melayu Pontianak dan Istana Kadriah yang biasanya mengambil dari unsur ragam alam serta interaksinya terhadap manusia, ragam flora, dan ragam geometris. Di dalam sebuah rumah tinggal tradisional Melayu Pontianak, ornamen (ragam hias) merupakan unsur yang bisa mempertegas fasade baik secara kualitas maupun citra yang akan diungkapkan terhadap bentuk bangunan. Motif ornament (ragam hias) nuansa khas budaya Melayu Pontianak yang sering digunakan yaitu berupa : motif daun-daunan, buah-buahan, sulur, bunga, tulisan kaligrafi arab, matahari, bulan, bintang, api, air, serta ornamen-ornamen yang berbentuk geometri.

Istilah fasade secara umum berasal dari bahasa Prancis yaitu facade yang artinya suatu sisi luar (eksterior) sebuah bangunan tampak depan, samping, dan belakang bangunan. Akar kata fasade (façade) diambil dari kata latin facies yang merupakan sinonim dari face (wajah) dan appearance (penampilan). Oleh karena itu, membicarakan wajah sebuah bangunan, yaitu fasade, yang kita maksudkan adalah bagian depan yang menghadap jalan. Ketika melihat sebuah bangunan yang pertama kali diamati adalah bagian muka (fasade) bangunan tersebut. Fasade merupakan bagian depan yang identik dengan face (wajah). Fasade juga dapat digunakan sebagai patokan/penanda untuk memberi penunjuk/gambaran bagi orang lain jika suatu ketika ditemukan masalah tentang letak suatu bangunan tertentu. Gambaran yang dapat diberikan melalui fasade misalnya berupa bentuk, keunikan gaya arsitektur atau kondisi fasade bangunan yang berbeda dari bangunan yang ada di sekitarnya. Dengan keunikan gaya arsitektur yang dimiliki sebuah bangunan maka bangunan itu akan mampu menarik perhatian orang jika melihatnya. Fasade adalah satu elemen bangunan yang berpengaruh pada fungsi serta aktivitas serta memberikan identitas bangunan terhadap publik.

Menurut Krier (1988:122),fasade adalah elemen dalam arsitektur yang dapat mengekspresikan fungsi dan maksud sebuah bangunan. Fasade merupakan elemen arsitektur terpenting yang mampu menyuarakan fungsi dan makna sebuah bangunan. Fasade tidaklah semata-mata mengenai memenuhi persyaratan alami yang ditentukan oleh organisasi dan ruang dibaliknya. Fasade menyampaikan keadaan budaya saat bangunan itu dibangun; fasade mengungkap kriteria tatanan dan penataan, dan berjasa memberikan kemungkinan dan kreativitas dalam ornamentasi dan dan dekorasi. Sebagai suatu keseluruhan, fasade tersusun dari elemen tunggal, suatu kesatuan tersendiri dengan kemampuan untuk mengekspresikan diri mereka sendiri. Elemenelemen tersebut alas, jendela, atap dan sebagainya karena sifat alaminya merupakan benda-benda yang berbeda sehingga memiliki bentuk, warna dan bahan yang berbeda (Krier, 1988: 123). Jadi, pemilihan elemen-elemen ini pertama-tama harus dikaitkan dengan bahasa fasade sebelumnya. Kontuniuitas sejati hanya dapat dipahami pada saat kualitas independen fasade yang baru beserta kondisi-kondisi serta tuntutan-tuntutannya yang baru dapat dipertahankan. Hubungan antara yang lama dan yang baru pada setiap kasus dapat diumpamakan sebagai sebuah dialog, percakapan antara masa lampau dan masa kini.

Juga oleh Tjahyono (1990) bahwa dasar perencanaan sebuah fasade bangunan memperhatikan pedoman yang berdasarkan pada sumbu kosmis utama. Bentuk fasade bangunan juga dimanifestasikan dengan antropometrik dengan tubuh manusia yaitu atap sebagai atas (kepala), badan sebagai bagian tengah dan bagian bawah sebagai kaki pada tubuh manusia. Dalam pandangan kosmologi tersebut, kehidupan dan dunia pembentuk merupakan satu kesatuan dan keseluruhan organis. Wilayah yang ia alami dianggap sebagai dunia yang teratur (sebagai kosmos) karena wilayah tersebut sudah dikonsentrasikan. Jadi wilayah kosmologi 
tersebut bisa kita pahami sebagai ruang atau bentuk yang terbatas dan memiliki suatu sistem dan keteraturan yang menaungi manusianya. Dalam skala yang lebih kecil, fasade bangunan juga merupakan wilayah kosmologi yang terbagi tiga yaitu :

Bagian atas atau kepala bangunan berupa atap dan penutup atap merupakan symbol dari dunia atas/ ilahi. Simbol ornamen pada bagian kepala memiliki pengertian semua ornamen maupun hiasan yang berada pada posisi atas suatu bangunan, yang fungsinya mempertegas ciri khusus dan nilai estetika bangunan tersebut, seperti ornamen pada pucuk atap, ornamen pada lisplank, ornamen pada genteng / kerpus, dsb.

Bagian tengah atau badan bangunan berupa dinding dan lantai merupakan symbol dari dunia yang didiami manusia. Simbol ornamen pada bagian badan memiliki pengertian semua ornamen maupun hiasan yang berada pada badan suatu bangunan, untuk menambah nilai estetika bangunan tersebut, seperti ornamen pada dinding/tembok, ornamen pada kolom, ornamen pada pintu, dsb.

Bagian bawah atau kaki bangunan berupa kolong atau tiang pondasi merupakan symbol dunia bawah/dunia orang mati (masa lalu). Simbol ornamen pada bagian kaki memiliki penertian semua ornamen maupun hiasan yang berada pada kaki suatu bangunan, selain berfungsi sebagai struktur bangunan jauga untuk menambah nilai estetika bangunan tersebut, seperti ornamen pada umpak / kaki kolom, ornamen pada lantai.

Dalam menyusun fasade bangunan publik terutama fungsi perkantoran diera saat sekarang ini terdapat usaha untuk menggabungkan langgam tradisional dengan perkembangan teknologi pada bangunan.. Hal ini sesuai dengan teori yang dikemukakan oleh Curtis dan Suha Ozkan mengenai regionalisme yang merupakan usaha peleburan dan penyatuan antara yang lama dan yang baru (Curtis,1985). Sebagai salah satu perkembangan arsitektur modern yang mempunyai perhatian besar pada ciri kedaerahan (berkaitan erat dengan budaya setempat, iklim, teknologi pada waktu itu) terutama tumbuh di negara berkembang (Ozkan, 1985).

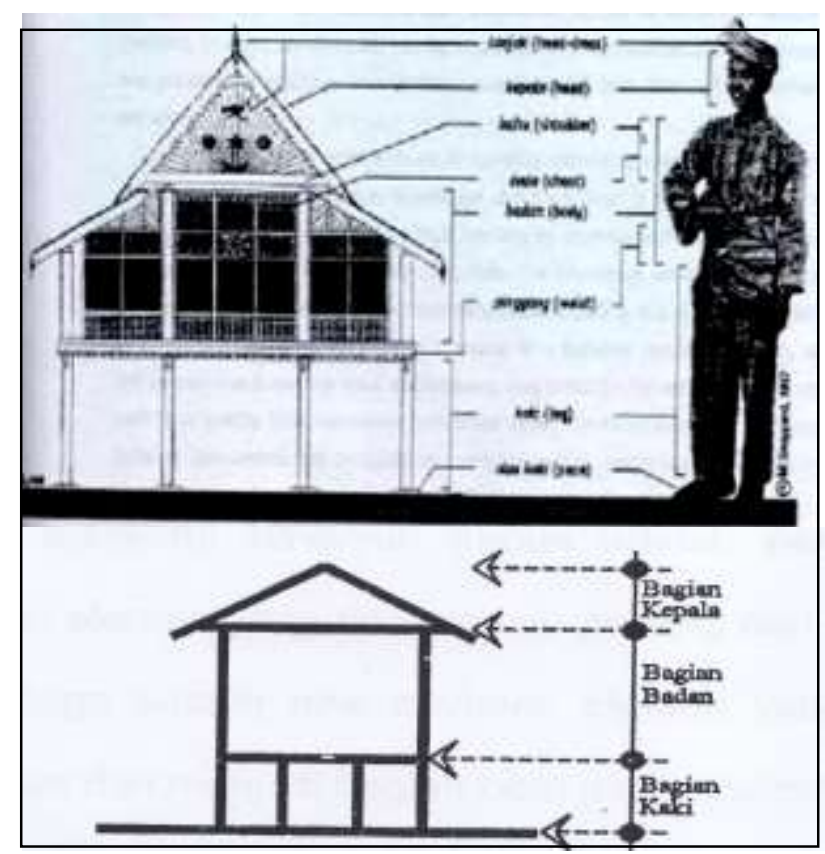

Gambar 1 : Bentuk Fasade Bangunan Yang Di Manifestasikan Dengan Antropometrik Tubuh Manusia dan Pembagian Wilayah Kosmologi ( Sumber : Ismail Zulkifli dkk., 2005; Tjahyono , 1990).

Bangunan publik adalah bangunan yang di peruntukan untuk masyarakat umum yang identik dengan pusat pelayanan masyarakat, baik yang berkaitan dengan kebutuhan pemerintahan, perekonomian, keamanan ataupun kebutuhan kebutuhan yang lain. Bangunan publik bersifat komunal dan umum, terbuka untuk semua kalangan sehingga tampilan fasade sebagai bagian terdepan dari bangunan lebih bersifat publik yang secara langsung berkomunikasi dengan masyarakat umum (Wiryomartono,1995; Peraturan Menteri PU No.29/PRT/M, 2006).

Terdapat berbagai contoh bangunan publik dilihat dari kegiatan yang dilakukan di dalam fasilitas bangunan tersebut yaitu bandar udara, terminal bis, tempat ibadah, stasiun kereta, pelabuhan kapal, landmark, gedung sekolah, gedung perkantoran pemerintahan dan pasar atau sentra bisnis (Peraturan Pemerintah Republik Indonesia Nomor 36, 2005). Menurut Barliana (2014) karena bangunan publik penggunanya bukan secara 
pribadi, beberapa hal yang perlu diperhatikan dalam bangunan publik tersebut antara lain: sign system yaitu system tanda yang dimunculkan pada bangunan publik harus dapat dibaca oleh target audiencenya dengan jelas. Sign system sendiri terdiri dari berbagai hal antara lain, wayfinding, traffic sign, signboard dan bentuk sign lain yang diterapkan pada interiornya. Sign system akan memudahkan pengguna dalam memanfaatkan fasilitas yang ada pada bangunan tersebut. Sign system merupakan graphic design yang diterapkan pada interior, hal-hal yang muncul dalam sign system antara lain pictogram (tanda yang harus memiliki keterbacaan secara umum, mudah dilihat, sederhana, konsisten, dan mudah digunakan), lettering, dan warna yang aman dan memiliki karakter.

Cara yang digunakan untuk menentukan aspek-aspek tolok ukur dalam membahas kajian pola ornamen (ragam hias) di sebuah bangunan yaitu dengan menggunakan teori dari N.J.Habraken (1978) yang mengatakan bahwa terdapat 3 (tiga) tolok ukur yang dapat dipandang sebagai kesatuan sistem yaitu terdiri dari : sistem fisik (physical system), system model (stylistic system), dan sistem spasial (spatial system). Untuk sistem fisik (physical system) dapat diidentifikasikan melalui berbagai aspek tolok ukur yang berkaitan dengan konstruksi elemen atas (kepala), elemen tengah (badan), dan elemen bawah (kaki) serta penggunaan materialmaterial yang digunakan dalam mewujudkan suatu fisik bangunan. Sistem ini mencakup hal-hal yang diidentifikasikan melalui tiang/kolom meliputi : menyangkut material, ukuran, besaran dan pola tatanan ( grid) dari tiang bangunan; lantai meliputi : menunjukkan pola, material dan derajat ketinggian lantai dari permukaan tanah; Dinding meliputi : menunjukkan jenis material yang digunakan, bukaan, dan Struktur Atap.

Kemudian untuk system model (stylistic system) dapat diidentifikasikan melalui berbagai aspek tolok ukur yang berkaitan dengan style atau langgam yang mewujudkan bentuk. Sistem ini meliputi fasade, bentuk pintu dan jendela serta unsur-unsur ornament (ragam hias) baik di dalam maupun di luar bangunan, karena pada dasarnya bentuk tatanan lingkungan fisik dapat dipandang sebagai suatu kesatuan sistem tersebut diatas. Sedangkan sistem spasial (spasial system) dapat diidentifikasikan melalui tata ruang dan terdapat berbagai aspek tolok ukur yang berkaitan dengan peruangan. Sistem ini mencakup organisasi ruang, hirarki ruang, orientasi ruang, dan hubungan ruangnya.

Pada dasarnya sebuah bangunan dapat dipandang sebagai suatu kegiatan sistem tersebut diatas. Walaupun ketiga aspek diatas merupakan satu kesatuan sistem namun terhadap konteks tertentu kaitannya dengan identifikasi sebuah rumah tinggal dapat berdiri sendiri. Dari ketiga pendapat Habraken ini tidak semuanya digunakan. Untuk teori N.J. Habraken (1978) yang akan digunakan dan relevan di dalam penelitian ini yaitu hanya menggunakan system model (stylistic system) saja.

\section{METODE}

Untuk menemukan jawaban dari rumusan masaalah dan pertanyaan penelitian, maka dalam penelitian terapan ini menggunakan metode pendekatan rasionalistik-kualitatif. Untuk penelitian terapan dengan metode pendekatan rasionalistik-kualitatif, peneliti menggunakan literatur (teori) secara konsisten berdasarkan asumsi-asumsi yang berasal dari para narasumber, yang tidak memberi ruang bagi pandangan pribadi peneliti. Penggunaan literatur (teori) di dalam penelitian kualitatif dapat dilakukan dengan cara memberikan penjelasan atas hubungan-hubungan yang diinginkan untuk menggambarkan teori yang akan digunakan dan menjelaskan mengapa teori tersebut penting untuk dikaji. Disini peneliti fokus pada teori-teori dalam berbagai literatur yang berhubungan dengan masalah yang diteliti.

Kemudian untuk pengambilan sampel penelitian terapan ini dilakukan terhadap keberadaan Istana Kadriah Pontianak dan populasi rumah tinggal tradisional Melayu Pontianak yang akan dibagi menjadi 3 (tiga) 
zona komunalitas yang tersebar di kota Pontianak, Kalimantan Barat meliputi : Zona A (Kampung Arab, Kampung Dalam Bugis, Kampung Tanjung Hilir), Zona B (Kampung Dalam Bugis, Kampung Tambelan Sampit), dan Zona C (Kampung Kamboja, Kampung Melayu Laut, Kampung Bangka Belitung, Kampung Bansir). Pertimbangan dipilihnya kota Pontianak sebagai lokasi penelitian untuk kasus rumah tinggal ini, karena lokasi tersebut merupakan area sebaran yang paling dominan untuk keberadaan rumah tinggal yang memiliki karakteristik Melayu Pontianak yang kuat (khas) jika dibandingkan dengan tempat yang lain.

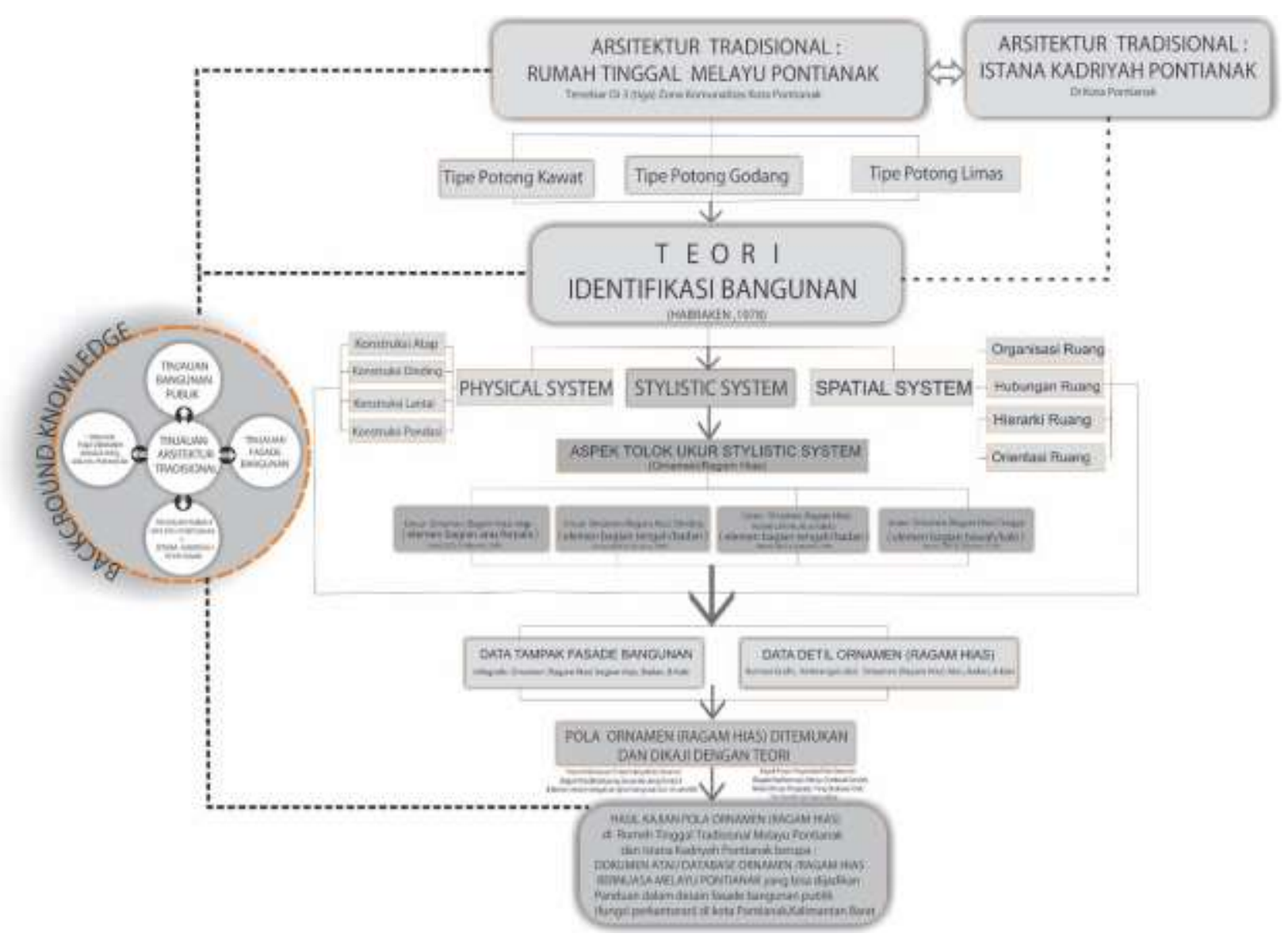

Gambar 2. Alur Rancangan Konseptual Penelitian

Sumber : Konstruksi Peneliti, 2019 Olahan dari John Ilahaw, John, 2004

Untuk jumlah sampel dalam penelitian terapan ini ditemukan pada saat kegiatan observasi lapangan sebanyak 1 unit Istana dan 30 unit rumah tinggal tradisional Melayu Pontianak di lokasi penelitian terapan. Hal ini dikarenakan dari pengelola Istana dan pemilik rumah tinggal tradisional Melayu Pontianak yang memberi izin kepada peneliti untuk melakukan pengukuran, pendokumentasian serta wawancara guna mencari informasi istana dan rumah tinggal tradisional Melayu Pontianak yang akan diteliti. Jumlah sampel penelitian terapan tersebut masih bisa bertambah oleh peneliti jika diberikan waktu yang relatif panjang berdasarkan jumlah populasi rumah tinggal tradisional Melayu Pontianak yang tersebar di berbagai lokasi penelitian disesuaikan dengan kriteria pemilihan sampel dalam penelitian tersebut.

Untuk melihat pola ornamen (ragam hias) bernuasa Melayu Pontianak yang bisa digunakan untuk fasade bangunan publik kota Pontianak, peneliti dapat memperhatikan variabel penelitian sistem model (stylistic 
system) yaitu meliputi Kategori Motif (Kategori Motif Fauna, Kategori Motif Flora, Kategori Motif Geometri, Kategori Motif Kaligrafi; Posisi/Letak (Bagian Kepala/Atas/Upper Side Structure, Bagian Badan/Tengah/Bottom Side Structure, Bagian
Kaki/Bawah/ Sub Structure); Bahan (Bahan Kayu, Bahan Logam, Bahan Kaca, Bahan Plastik); dan Warna (Warna Coklat, Warna Putih, Warna Hijau, Warna Emas).

\section{HASIL}

Tabel 1. Model Identifikasi Sistem model (Stylistic System) di Istana Kadriah dan rumah tradisional Melayu Pontianak di Zona Komunalitas A, B,C

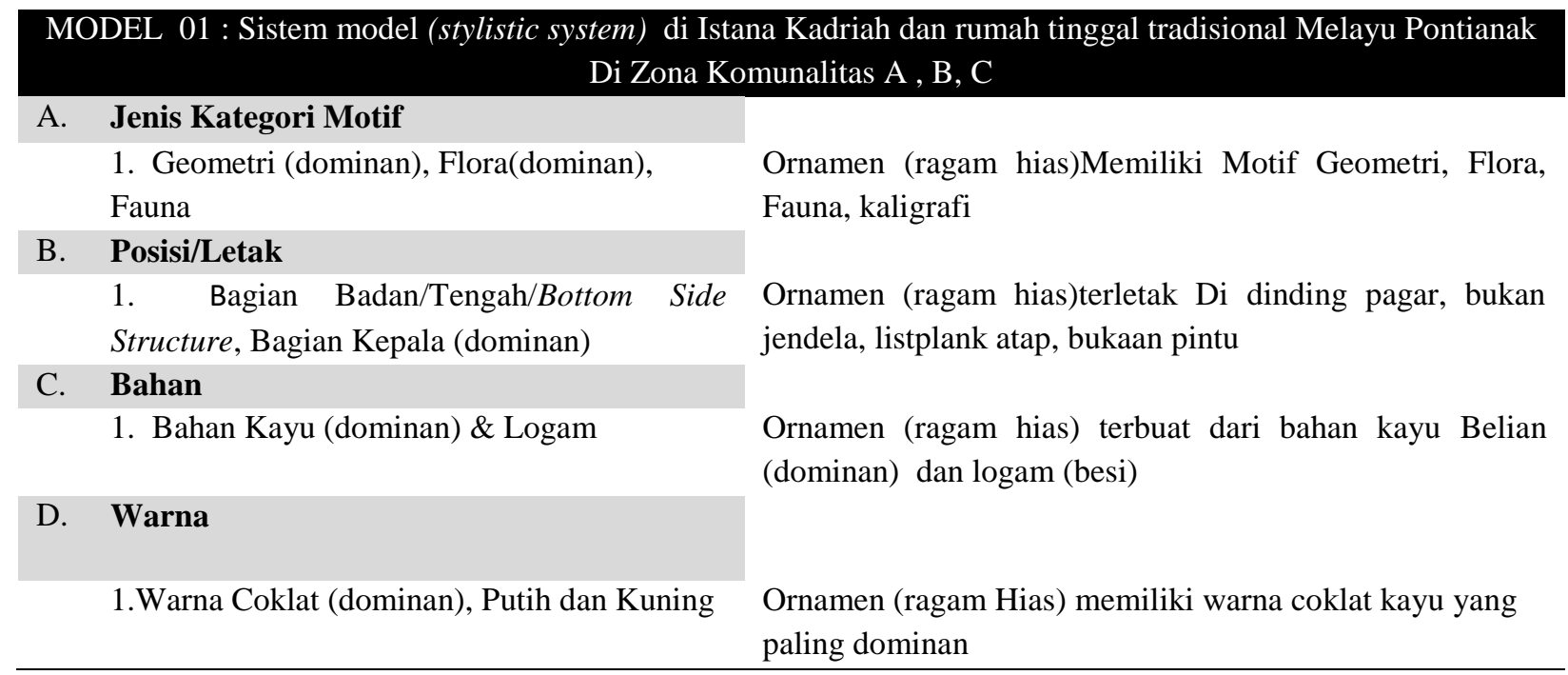

Sumber : Hasil Analisis, 2019

\section{PEMBAHASAN}

Berdasarkan hasil analisis penelitian terapan dari sampel penelitian meliputi : Istana Kadriah dan rumah tinggal tradisional Melayu Pontianak di zona komunalitas A R.A1 s/d R.A10, zona komunalitas B R.B1 s/d R.B10, dan zona komunalitas C R.C1 s/d R.C10 dapat digambarkan serta dikelompokan ke dalam sebuah matrik sistem model (stylistic system) yaitu meliputi Kategori Motif (Kategori Motif Fauna, Kategori Motif Flora, Kategori Motif Geometri, Kategori Motif Kaligrafi; Posisi/Letak (Bagian Kepala/Atas/Upper Side Structure, Bagian Badan/Tengah/Bottom Side Structure, Bagian Kaki/Bawah/ Sub Structure); Bahan (Bahan Kayu, Bahan Logam, Bahan Kaca, Bahan Plastik); dan Warna (Warna Coklat, Warna Putih, Warna Hijau, Warna Emas).

Pembuatan matrik Identifikasi ornament (ragam hias) Istana Kadriah dan rumah tinggal tradisional Melayu Pontianak dengan variabel penelitian sistem model (stylistic system) rumah tinggal tradisional Melayu Pontianak bersumber pada visualisasi fakta-fakta yang ditemukan di lapangan. Sementara itu, mengenai identifikasi ornament (ragam hias) Istana Kadriah dan rumah tinggal tradisional Melayu Pontianak dengan variabel penelitian sistem model (stylistic system) dalam Teori N.J. Habraken dengan membuat dokumentasi gambar ornament (ragam hias) rumah tinggal tradisional Melayu Pontianak setiap sampel (kasus) untuk dijadikan bahan analisa dalam proses analisis data.

Didalam identifikasi ornament (ragam hias) Istana Kadriah dan rumah tinggal tradisional Melayu Pontianak dengan variabel penelitian System model (stylistic system) rumah tinggal tradisional Melayu Pontianak yang dijabarkan di tabel 01 menjelaskan adanya temuan 1 model identifikasi sistem model (stylistic system) Istana Kadriah dan rumah tinggal tradisional Melayu Pontianak di zona komunalitas $\mathrm{A}, \mathrm{B}$ dan $\mathrm{C}$ yang secara umum menunjukkan adanya keberagamaan data temuan yang bersifat geometris 
dijabarkan hanya yang dominan atau yang sering muncul saja di masing-masing sampel penelitian terapan. Untuk masing-masing dapat dijelaskan didalam tabel 1.

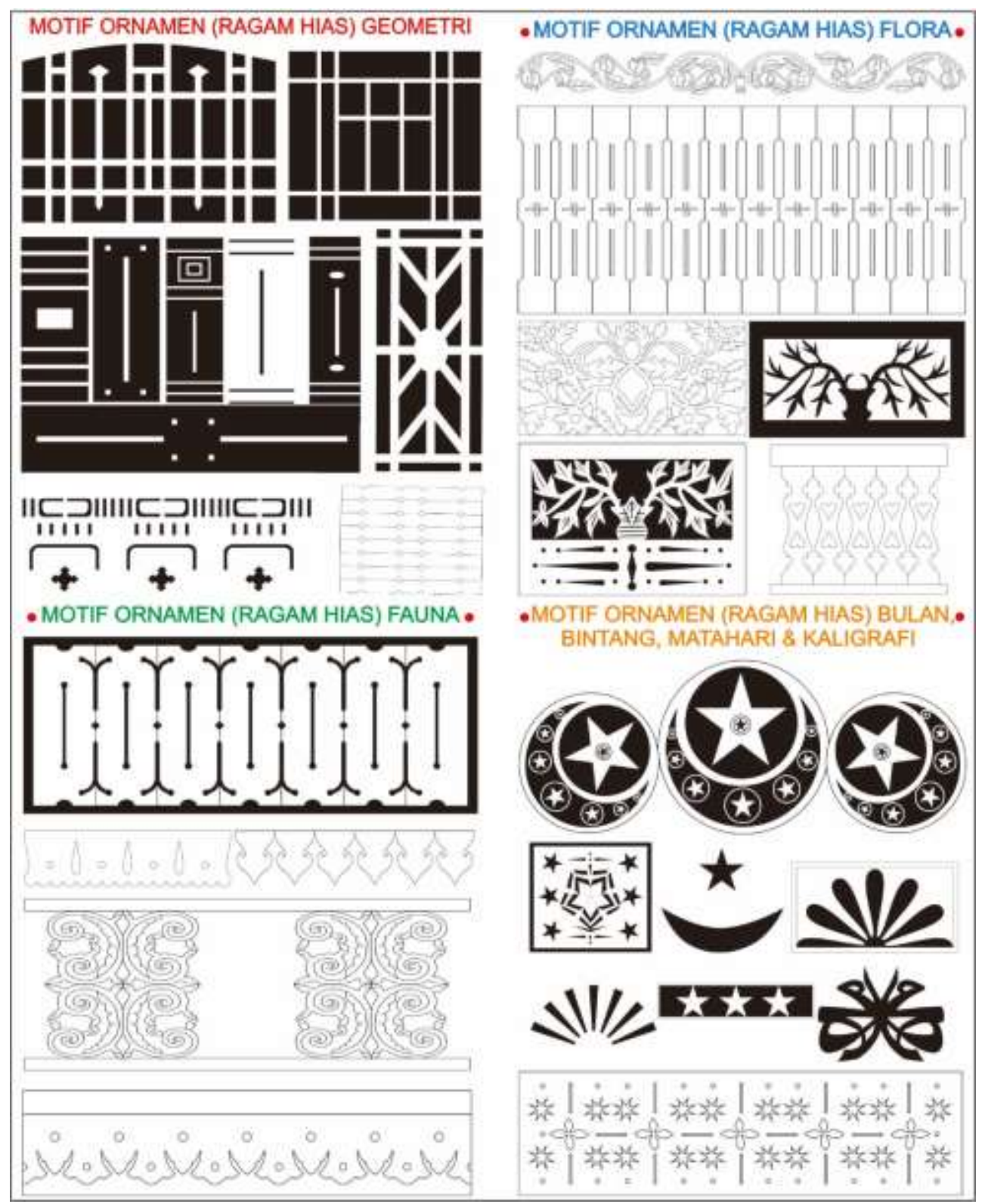

Gambar 3 : Beberapa Bentuk Pola Ornamen (Ragam Hias) Bernuansa Melayu Pontianak Yang Bisa Di Manifestasikan pada Fasade Bangunan Publik

Sumber : Hasil Analisis \& Pembahasan Peneliti, 2019

Berdasarkan temuan identifikasi pola ornament (ragam hias) di Istana Kadriah Pontianak dan rumah tinggal tradisional Melayu Pontianak dengan variabel penelitian sistem model (stylistic system) yang dapat digunakan untuk fasade bangunan public di kota Pontianak yaitu kategori motif geometri lebih dominan dibanding motif fauna, motif flora dan motif kaligrafi; posisi/letak bagian badan/tengah/bottom side structure lebih dominan dibanding dengan bagian kepala/atas/upper side structure dan bagian kaki/bawah/ sub structure); bahan kayu dan bahan logam lebih dominan dengan bahan kaca, bahan plastik; serta pemakaian warna 
coklat lebih dominan dibanding pemakaian warna putih, warna hijau, warna emas).

Didalam Istana Kadriah dan rumah tinggal tradisional Melayu Pontianak, pola ornamen (ragam hias) yang digunakan merupakan unsur yang bisa mempertegas fasade baik secara kualitas maupun citra yang akan diungkapkan terhadap bentuk bangunan. Hal ini juga bisa digunakan juga untuk pola ornamen (ragam hias) di fasade bangunan public di Pontianak.

Sebagai ragam hias simbolis dibuat selain mempunyai fungsi sebagai penghias suatu bangunan publik juga memiliki nilai simbolis tertentu didalam norma-norma tertentu (adat, agama, sistem sosial lainnya). Bentuk, motif dan penempatannya sangat ditentukan oleh norma-norma adat maupun agama untuk menghindari timbulnya salah pengertian akan makna atau nilai simbolis yang terkandung didalamnya, oleh sebab itu pengerjaan suatu ornamen simbolis pada fasade bangunan public di kota Pontianak hendaknya menepati aturan-aturan yang ditentukan. Contoh ornament (ragam hias) ini misalnya motif kaligrafi, motif flora, motif fauna dan motif geometri.

\section{SIMPULAN}

Berdasarkan hasil analisis dan pembahasan penelitian yang dilakukan dapat disimpulkan bahwa didalam identifikasi pola ornament (ragam hias) yang bisa diterapkan pada fasade bangunan public di kota Pontianak dengan variabel penelitian System model (stylistic system) menjelaskan adanya temuan 1 model identifikasi sistem model (stylistic system) Istana Kadriah, rumah tinggal tradisional Melayu Pontianak di zona komunalitas $\mathrm{A}, \mathrm{B}$ dan $\mathrm{C}$ yang secara umum menunjukkan adanya keberagamaan data temuan yang dijabarkan hanya yang dominan atau yang sering muncul saja di masingmasing sampel penelitian terapan yaitu kategori motif geometri lebih dominan dibanding motif fauna, motif flora dan motif kaligrafi; posisi/letak bagian badan/tengah/bottom side structure lebih dominan dibanding dengan bagian kepala/atas/upper side structure dan bagian kaki/bawah/ sub structure); bahan kayu dan bahan logam lebih dominan dengan bahan kaca, bahan plastik; serta pemakaian warna coklat lebih dominan dibanding pemakaian warna putih, warna hijau, warna emas).

Dengan melihat dasar motif ornamen yang digunakan, maka unsur warna yang mempengeruhi ornamen (ragam hias) khas budaya Melayu Pontianak juga diambil dari warna yang dominan dari semua unsur tersebut, yaitu meliputi : warna hijau, kuning (keemasan), putih, dan merah. Adapun penempatan motif ornamen (ragam hias) khas budaya Melayu Pontianak pada umumnya diletakkan pada posisi tempat di dalam atau di luar ruang yang bisa terlihat langsung seperti pada : bubungan, sudut atap, balok, dinding, bidai/sampir (dinding pembatas dalam ruangan), pintu, jendela, listplank, tangga, pagar, tiang, balk kasau, dan pada sambungan kayu. Dan motif ornament (ragam hias) nuansa khas budaya Melayu Pontianak yang sering digunakan yaitu berupa : motif daun-daunan, buah-buahan, sulur, bunga, tulisan kaligrafi arab, matahari, bulan, bintang, api, air, serta ornamen-ornamen yang berbentuk geometri

\section{DAFTAR PUSTAKA}

Alexander, Christopher. 1977, A Pattern Language: Towns, Buildings, Construction, New York: Oxford University Press.

Arinto dkk, 1982, Ragam Hias dan Beberapa Upacara, Materi Penelitian II bagi kerangka laporan Inventarisasi dan Dokumentasi Arsitektur Tradisional Proyek IDKD Dep. P dan K, Salatiga.

Barliana, M. Syaom dan Diah Cahyani, 2014, Arsitektur, Urbanitas, dan Pendidikan Budaya Berkota, Yogyakarya : Penerbit Deepublish.

Baskoro,Wahyu. 2005, Kamus Lengkap : Bahasa Indonesia Dengan Ejaan Yang Disempurnakan, Penerbit Setta Kawan, Jakarta. 
Curtis, William, 1985, Regionalism in Architecture dalam Regionalism in Architecture, editor Robert Power, Singapore : Concept Media.

Danna Marjono, Suyatno. 1979, Pendidikan Seni Rupa, Pustaka Antara, Jakarta.

Dagun, M. Save,1997, Kamus Besar Ilmu Pengetahuan, Penerbit Lembaga Pengkajian Kebudayaan Nusantara (LPKN), Jakarta.

Djafar Said dkk.,1997, Catatan Ragam Hias Kalimantan Barat, Penerbit Dewan Kerajinan Nasional Daerah TK.1 Kalimantan Barat, Indonesia.

Habraken, N, John, 1978, The Systematic Design of Support, Massachusset: Laboratory Of Arch And Planning MIT, Cambridge.

Hassanudin, Purwana,B.H.S dan Sulistiorini P., 2000, Pontianak 1771 - 1900 Suatu Tinjauan Sejarah Sosial Ekonomi, Romeo Grafika, Pontianak.

Isman, Zainuddin, 2001, Orang Melayu Di Kalimantan Barat : Kajian Perubahan Budaya Pada Komuniti Pesisir Dan Komuniti Pedalaman, Tesis S2 Tidak Diterbitkan ,Institut Alam Dan Tamadun Melayu,Universiti Kebangsaan Malaysia,Bangi.

Ihalauw,J.O.I John, 2004, Bangunan Teori, Satya Wacana University Press, Salatiga.

Iswanto, Danoe, 2008, Aplikasi Ragam Hias Jawa Tradisional Pada Rumah Tinggal Baru, Jurnal Enclosure, Vol. 7 No. 2.

Ismail Zulkifli dkk., 2005, Modularity Concept In Traditional Malay House (TMH) In Malaysia,Dept. Of Architecture \& Environment Design, Internasional Islamic University Malaysia, Kuala Lumpur, Malaysia

Krier, Rob, 1988, Architectural Composition, Rizzoli, New York.
Muhadjir, Noeng H, 2000, Metodologi Penelitian Kualitatif. Revisi IV. Penerbit Rake Sarasin. Yogyakarta.

Oxford and Oxford English, 1991, Oxford Learner's Pocket Dictioanry, Oxford University Press, New York.

Ozkan, Suha, 1985, Regionalism within Modernism dalam Regionalism in Architecture, editor Robert Power, Singapore : Concept Media.

Peraturan Pemerintah Republik Indonesia Nomor 36 Tahun 2005 Tentang Peraturan Pelaksanaan UndangUndang Nomor 28 Tahun 2002 Tentang Bangunan Gedung.

Peraturan Menteri PU No.29/PRT/M/2006 Tentang Pedoman Persyaratan Teknis Bangunan Gedung.

Poerwadarminta,W.J.S., 1976, Kamus Umum Bahasa Indonesia,Penerbit Balai Pustaka,Jakarta.

Purwana,B.H.S.dkk,2004,Sejarah Pemerintahan Kota Pontianak Dari Masa Ke Masa, Penerbit Romeo Grafika, Pontianak.

Rapoport, Amos, 1969, A. House, Form and Culture, Prentice Hall, New York.

Rapoport, Amos, 1989, Dwelling Settlement And Tradition, London, Prentice Hall Inc.

Sinar, Tengku Luckman, 1989, Motif Dan Ornamen Melayu, Lembaga Pembinaan dan Pengembangan Seni Budaya Melayu

Sugono, Dendy dkk, 2008, Kamus Besar Bahasa Indonesia: Pusat Bahasa, Edisi Keempat,Penerbit Departemen Pendidikan Nasional,Jakarta.

Santosa, Imam, 2017, Karakteristik Bentuk Dan Fungsi Ragam Hias Pada Arsitektur Masjid Agung Kota Bandung, Jurnal Sosioteknologi, Vol.16 No. 3.

Tjahjono, Gunawan, 1990, Cosmos,Center And Duality In Javanese Architecture Tradition;The Symbolic Dimension Of 
House Shapes In Kotagede And Surroundings, Dissertatiion Doctor Of Phylosophy,University of California at Berkeley.

The Collin's English, 1986, English Dictionary : 2nd ed., Collins Publisher, Sydney.

Usmardan,Syarif,1998,Karakter

Fisik

Kawasan Permukiman Sekitar Istana

Kadriah Pontianak,Tesis S2 Tidak Diterbitkan, Program Pascasarjana, Program Studi Arsitektur, Jurusan IlmuIlmu Teknik, Universitas Gadjah Mada,Yogyakarta.

Veth, P. J., 1854, Borneo's Wester-Afdeeling : Geographisch, Statistisch, Historisch, Voorafgegan door een algemene Schets der gansche eilandsDeel I Zaltbommel.

Wiryomartono, Bagoes, 1995, Seni Bangunan dan Seni Bina Kota di Indonesia, Jakarta: Gramedia.

Wuryanto,Hery, dkk, 1986, Arsitektur Tradisional Daerah Kalimantan Barat, Departemen Pendidikan Dan Kebudayaan, Proyek Inventarisasi Dan Dokumentasi Kebudayaan Daerah, Jakarta.

Wati, Arena, 1989, Syair Pangeran Syarif, Penerbit Universiti Kebangsaan Malaysia,Bangi.

Yunus, S. Hadi,1987,Permasalahan Daerah Urban Fringe Dan Alternatif Pemecahannya, Makalah Kursus Perencanaan Pembangunan regional Untuk Penyusunan Kerangka Pembangunan Strategis (KPS),Fakultas Geografi UGM Bekerja Sama Dengan BAPPEDA Propinsi Dati I, Yogyakarta. 